DOI https://doi.org/10.36059/978-966-397-225-1-14

\title{
INTEGRATION WAYS OF CHOREOGRAPHIC ART AND SPORT
}

\section{Sosina Valentyna}

\section{INTRODUCTION}

Analysis of the reasons for the integration of modern choreographic art and technical and aesthetic sports, which are associated with the manifestation of the movement culture, is one of the current and littlestudied problems. Factors of mutual penetration relate to historical aspects of both human activities, aesthetic requirements, the importance of artistry and expressiveness, similar means and methods of teaching and education, similar techniques of choreographic exercises, the presence of a pre-arranged program of action (composition), the need for musical accompaniment, requirements for morpho-functional indicators and physical development data of dancers and athletes, design of performances, costumes, etc.

Along with the growth of skill in performing dance parts and perfect presentation of sports compositions, which are actively enriched through mutual penetration, synthesis and borrowing, the process of researching possible integration areas of choreographic and circus arts and sports has intensified.

The first steps in this direction have already been taken in previous publications ${ }^{1}$. The new study allows us to clarify the problem and supplement the data on common features, fundamental differences and possible ways of mutual enrichment of these two elements of culture.

The purpose of the study - based on the analysis of common and distinctive features of choreographic art and technical and aesthetic sports to identify possible ways of their integration, which are able to fruitfully influence and complement each other.

The first part of the study is devoted to the analysis of the features that unite and distinguish choreographic art and sports, in the second possible ways of mutual enrichment and their development in the future are considered.

${ }^{1}$ Sosina V. Yu. (2018) Shliakhy intehratsii khoreohrafichnoho mystetstva ta tekhnikoestetychnykh vydiv sportu [Shlyakhi of integration of choreographic art and technicalaesthetic types of sports]. Dance Studies, vol. 1, pp. 81-90. 


\section{Analysis of Common and Different Features of Choreographic Art and Sport}

Sports and dance have a lot in common. Modern ballet is a complex synthesis of classical choreography, circus art, stunning supports and pyramids, elements of free plasticity art, exercises of artistic, aesthetic and sports gymnastics, which organically included elements of modern dance and its many directions and styles ${ }^{2}$. In modern society, art and sports have become so close that it is now difficult to say what prevails in ballet performances and performances of dancers - choreography, complexity and risk, elements of sport or acrobatics; and in the performances of athletes the art of owning their body, choreographic presentation of competitive programs or aesthetic embodiment of the plot of the composition? This question worries scientists, theorists and practitioners, but so far there are no and most likely no sound arguments in favor of any answer.

Exercise in both activities improves the physical and functional capabilities of the body, strengthens muscles, forms the correct posture, promotes harmonious development. In addition, they increase self-discipline, responsibility, cultivate a range of moral and volitional qualities. Dance skills help athletes develop coordination, jumping and speed, cultivate plasticity, purity and accuracy of motor actions Exercise in both activities improves the physical and functional capabilities of the body, strengthens muscles, forms the correct posture, promotes harmonious development. In addition, they increase self-discipline, responsibility, cultivate a range of moral and volitional qualities. Dance skills help athletes develop coordination, jumping and speed, cultivate plasticity, purity and accuracy of motor actions. The skills of collective interaction are essential for athletes in team sports, when it is necessary to show the coordinated synchronous performance of movements in a competitive program (group exercises of rhythmic gymnastics, pair-group exercises of acrobatics, formation in sports dances, compositions in artistic swimming, etc.). Such skills and abilities are formed in the process of performing group dances, when athletes learn to coordinate their movements, coordinating them with the movements of other team members. At the same time, artists of dance genres successfully use an effective system of special physical and technical training, perfectly developed in sports.

At the heart of both types is the public presentation of the results of their activities at the discretion of the audience - the theatre as well as sports

\footnotetext{
${ }^{2}$ Sosina V. Yu. (2018) Shliakhy intehratsii khoreohrafichnoho mystetstva ta tekhnikoestetychnykh vydiv sportu [Shlyakhi of integration of choreographic art and technicalaesthetic types of sports]. Dance Studies, vol. 1, pp. 81-90.
} 
competitions do not exist without the public. Spectators in the theatre may not perceive the poor staging or performance of the actors, as well as in the sports stands may not support the athlete in a difficult moment. It is for spectators and fans that athletes try to show a "beautiful game", demonstrating not only sportsmanship but also artistry ${ }^{3}$.

Complicating the choreographic vocabulary of a modern ballet performance, increasing the amplitude of most dance movements makes you turn to the data of anatomy, biomechanics, kinesiology, borrow certain exercises from certain sports (including rhythmic gymnastics, acrobatics, figure skating, namely, skating and others), as this allows to optimize the learning process significantly. In addition, the development of motor skills required in the profession of a ballet dancer (coordination, endurance, muscle strength, flexibility, jumping, etc.) will not be effective without taking into account scientific research in sports theory and practice, according to S. I. Radchenko ${ }^{4}$.

The criteria for the artistic performance of the composition of athletes include the same indicators that are of great importance in the art of choreography, determine the spectacle and originality of the production, as well as the artistry of its performers ${ }^{5}$.

However, in ballet theatre, spirituality is embodied through the inner need of the performer to think deeply, feel and accumulate value aspects in order to later reflect all this in a dance-plastic stage image, using conditionally generalized language.

In classical dance, there is a language of body positions, poses, gestures, pantomime and imitation of action, which are one of the ancient means of expression of a choreographic work, the transfer of its plot. The manifestation of spirituality in technical and aesthetic sports is somewhat different, where the gesture is designed primarily to create external

${ }^{3}$ Prokopovich L. V. (2018) Issledovanie artistizma i teatral'nosti v sporte kak v kul'turnoy praktike [Research of artistry and theatricality in sport as in cultural practice]. Molodyi vchenyi, no. 7 (2), pp. 350-353.

${ }^{4}$ Radchenko S. I. (2020) Perspektivnye napravleniya sovershenstvovaniya metodiki prepodavaniya klassicheskogo tantsa $\mathrm{V}$ sisteme srednego professional'nogo khoreograficheskogo obrazovaniya [Prospective directions of improving the methods of teaching classical dance in the system of secondary professional choreographic education]. Pedagogika iskusstva [Pedagogy of Art] (electronic journal), no. 1, pp. 111-118. Retrieved from: http://www.art-education.ru/sites/default/files/journal_pdf/radchenko_ 111-118.pdf (accessed 7 October 2020).

5 Sosina V. Yu. (2018) Shliakhy intehratsii khoreohrafichnoho mystetstva ta tekhniko- estetychnykh vydiv sportu [Shlyakhi of integration of choreographic art and technical-aesthetic types of sports]. Dance Studies, vol. 1, pp. 81-90. 
effectiveness, its purpose is to give brightness and richness to the performance of the athlete.

Modern technical and aesthetic sports are becoming more and more "artistic", which is regulated by the rules of competition, entertainment, music, costumes. It is no longer enough for athletes to show super-complex, risky, original and unique elements in conditions of fierce competition, it is necessary to show a high level of artistic ability, to reproduce all this in a competitive composition composed according to all the laws of choreography. It is a perfectly designed composition in technical and aesthetic sports that often decides the final result of competitions.

To assess the technique and artistic performance of competitive compositions in these sports involved two teams of judges, who according to different criteria determine the performance of athletes, which is assessed by musicality, consistency of movements with the tempo and rhythm of music, dance, illustrative and emotional expressiveness, ability to create emotionally motor image, elegance, amplitude, purity and accuracy of movements, etc. ${ }^{6,7}$.

One cannot disagree with the importance of motor skills acquired by dance artists in the process of studying the elements of sports (rhythmic and gymnastics, acrobatics, trampoline jumping). The same goes for athletes - in the process of choreographic training they master new forms of movement, expressiveness, hone their skills, form the correct posture, which helps to improve sports results.

A feature of choreographic and sports compositions in technical and aesthetic sports are the compositions created in advance by the choreographer or choreographer-coach, which after repeated repetition are evaluated by spectators and judges. In sports, they say that they have a "programmatic nature", which means the invariability of the sequence of actions, combinations, elements. All compositions are performed to musical accompaniment, which must correspond to the character, style, the genre of the composition, and in sports - even a strictly defined time. Highly artistic music combined with dance exercises, original compositional ideas - all this combines choreography and modern technical and aesthetic sports.

To achieve a high level of performance skills of dancers and athletes in technical and aesthetic sports use similar tools, methods and techniques for

6 Sosina V. Yu. (2018) Shliakhy intehratsii khoreohrafichnoho mystetstva ta tekhniko- estetychnykh vydiv sportu [Shlyakhi of integration of choreographic art and technical-aesthetic types of sports]. Dance Studies, vol. 1, pp. 81-90.

${ }^{7}$ Sosina V. Yu. (2019) Khoreohrafiia v sporti [Choreography in sports]. Kyiv: Olimpiyska Literatura. 
the formation of motor skills, development of physical qualities and abilities. It is known that sports, which are characterized by competitive activities, can make greater use of game and competitive methods of learning and training. However, the same methods are quite acceptable in dance groups as effective and emotional. An example is a competition ("battles"), which have become popular among representatives of modern dance style breakdance.

Despite the specific features of the technique of performing choreographic elements in sports and choreography, in both activities, it is impossible to achieve mastery without the use of classical exercise at the support and in the middle of the hall. It is the systematic performance of classical exercise exercises that provides the correct technique for performing choreographic exercises, the main criterion of quality and efficiency of which is purity, lightness, ease, naturalness and expressiveness.

Despite the fact that the training of dancers and athletes is based mainly on the classical basis, but in both activities, it is mandatory to study historical and domestic, folk, ballroom and modern dances. And this is declared in sports curricula and programs for children's dance groups and choreographic schools.

Enrichment of the motor arsenal with new exercises, the formation of new motor skills and related motor skills allows dancers and athletes to improve performance skills, develop the necessary physical qualities and motor skills.

To improve pirouettes and balance, strengthen the muscles of the lower leg and foot in sports training, the technique of performing elements of classical pointe dance is often used. Despite the fact that in sports the list of exercises on pointe is quite limited and has only an auxiliary character, they allow athletes to feel the strict plasticity forms and an impeccably worked out technique ${ }^{8}$.

One of the important tasks of choreographic training in sports is to "dance, cause a desire to dance" athletes, as they often have a limited dance supply and lack of freedom, ease of movement. To do this, invite dancers of different directions and styles, which allows athletes to develop plasticity, musicality, freedom of movement and artistry.

Elements of circus art (juggling various objects: balls, clubs, hoops) are actively introduced into rhythmic gymnastics, the technique of possession of these subjects is copied.

In ballet or other types of choreographic art, there is an active introduction of acrobatics and gymnastics elements. However, it should be noted that such

${ }^{8}$ Panasenko Yu.V. (ed.) (2019) Tantseval'naya pedagogika budushchego: teoriya $i$ praktika [Dance pedagogy of the future: theory and practice]. Materials of the International Scientific and Practical Conference of the Dancehelp company in conjunction with the Moscow State Budgetary Institution of Culture "CC "Inspiration" (Russia, Moscow, July 13, 2019). Moscow: ROSA, p. 217. 
interpenetration must have certain limits, which are limited by the characteristics of the professional features of ballet-dancers or dancers, as well as the rules of competition in sports. For example, the rules of competitions in certain technical and aesthetic sports prohibit the replacement of the sports component of the composition by dance, and the use of dance elements in more than half of the composition leads to its non-enrollment or significant losing points in the performance.

The modern technique of many choreographic elements has changed so much due to the introduction of a sporty style of their performance that it is now impossible to say who first initiated this innovation. A clear example of this fact can be the technique of jumping, which in ballet has acquired a "sporty" amplitude, and in sports - signs of "male complexity" 9.

Integration, synthesis of art and sports have a long tradition. Attempts to unite for the first time were made in ancient Greece, which left us with immortal works in all fields of art. Suffice it to mention the words of one of the most famous philosophers of the ancient world - Plato, who said that God gave man two abilities: music and gymnastics, for temperament and for the commitment to wisdom, so that they unite in harmony, and each of them should be tightened and released until they sound consistent, as required ${ }^{10}$.

Under the integration of sports and art is understood, firstly, the process and result of the convergence of these two elements of culture on a number of parameters; secondly, the process and result of firming the connection, strengthening the interaction between them ${ }^{11,12}$.

Issues related to the aesthetics of sports are the subject of research by many experts. For example, one of the founders of modern gymnastics, Pierre Ling, emphasized that the purpose of this sport is to convey thoughts and feelings through movements that should be attractive to the eyes. The

${ }^{9}$ Sosina V. Yu. (2018) Shliakhy intehratsii khoreohrafichnoho mystetstva ta tekhnikoestetychnykh vydiv sportu [Shlyakhi of integration of choreographic art and technicalaesthetic types of sports]. Dance Studies, vol. 1, pp. 81-90.

${ }^{10}$ Aleksanyan S., Koyumdzhyan E., Sharina O. (2016) Sredstva i metody khoreografii $v$ tantseval'noy aerobike [Means and methods of choreography in dance aerobics]. Yekaterinburg: Ural University Publishing House.

11 Stolyarov V. I., Samusenkova V. I. (1996) Sovremennyy sport kak fenomen kul'tury i puti ego integratsii $\mathrm{s}$ iskusstvom (teoriya, metodologicheskie podkhody, programmy) [Modern sport as a cultural phenomenon and ways of its integration with art (theory, methodological approaches, programs)]. Sport $i$ iskusstvo: al'ternativa edinstvo - sintez? [Sport and art: alternative - unity - synthesis?] (Vol. 3.). Moscow: Humanitarian Center "Spart” RGAFK, pp. 49-178.

${ }^{12}$ Stolyarov V. I. (1997) Sport i iskusstvo: skhodstvo, razlichie, puti integratsii [Sport and art: similarity, difference, ways of integration]. Sport, dukhovnye tsennosti, kul'tura [Sport, spiritual values, culture]. (Vol. 5). Moscow: Humanitarian Center "Spart" RGAFK, pp. 101-265. 
American scientist B. Lowe in his book "The Beauty of Sport" discusses in detail the question of whether sport can be considered an art, and the athlete can be considered an artist. Giving a positive answer, the author writes: “... as paint and canvas for a painter, the own body serves the athlete to demonstrate the art. And his art can exist both for the sake of the process itself (the process of self-expression) and for the sake of the result (including public recognition and material reward)"13.

According to S. V. Kotov, gymnastics is one of the sports where the advantage of aesthetics often decides the end result of athletes' performances $^{14}$.

Throughout its development, choreography has been inextricably linked to physical culture and sports. Georges Demeny's system of music and rhythm education, Isadora Duncan's dance gymnastics, François Delsart's expressive gymnastics, Jacques Dalcroze's free plastic movements, Monica Beckman's jazz gymnastics, Jackie Sorensen's aerobic dances, Martha Graham's synthesized modern dance technique, one side, others influenced the development of modern dance arts, on the other hand, contributed to the emergence and formation of new sports associated with the manifestation of the culture of movement and choreography. Many representatives of national systems of physical education included elements of choreography in their classes, arguing that dancing and physical exercises to music develop good posture, gait, the plasticity of movements, strength and endurance.

Thus, the founders of Swedish gymnastics Pierre (1776 - 1839) and Hjalmar Ling $(1820$ - 1886) pointed to the need of using dance movements during exercise and called it aesthetic gymnastics.

Francisco Amoros (1767 - 1848), a representative of the French school, considered choreography as one of the obligatory components of physical education, which had a positive effect on the activity of the nervous system, formed posture, and developed the musculoskeletal system. The means of physical education included dancing, elementary (free) exercises, which were accompanied by music and singing.

${ }^{13}$ Stolyarov V. I. (1997) Sport i iskusstvo: skhodstvo, razlichie, puti integratsii [Sport and art: similarity, difference, ways of integration]. Sport, dukhovnye tsennosti, kul'tura [Sport, spiritual values, culture]. (Vol. 5). Moscow: Humanitarian Center "Spart" RGAFK, pp. 101-265.

${ }^{14}$ Panasenko Yu.V. (ed.) (2019) Tantseval'naya pedagogika budushchego: teoriya $i$ praktika [Dance pedagogy of the future: theory and practice]. Materials of the International Scientific and Practical Conference of the Dancehelp company in conjunction with the Moscow State Budgetary Institution of Culture "CC "Inspiration" (Russia, Moscow, July 13, 2019). Moscow: ROSA, p. 217. 
French physiologist and educator, author of the gymnastic system of physical education Demeny Georges $(1850-1917)$, is considered one of the founders of modern rhythmic gymnastics.

Another representative of France is the educator and composer Francois Delsart (1881 - 1971), known as the founder of the principles of the relationship between emotional experiences, gestures and facial expressions. His expressions "poetry of the body" and "the body never deceives" have become symbols of today's modern ballet. The works of F. Delsart and his followers formed the basis of the theory of expressive movement and influenced the development of ballet and pantomime, served as a foundation for the creation of a rhythmic direction in gymnastics.

Jacques Dalcroze, music and singing teacher from Geneva (1865-1950), first used rhythm training as preparation for playing musical instruments, and later promoted rhythm as an effective means of educating the will, strengthening physical and spiritual health, and harmonious human development. It was he who first introduced the term "rhythmic gymnastics"15.

J. Dalcroze's method was based on an organic combination of music and movements.

Among the phenomena that aroused increased interest among women not only in ballet, pantomime but also in gymnastics, which developed a culture of movement, expressive plasticity, we must mention the art of Isadora Duncan (1877-1927). The peculiarity of the art of this famous dancer was the revival of classical ancient dance, built on the laws of free sculpture, the introduction of pantomime element in the dance, movements and principles of jazz dance, which together with jazz music conquered the world. Quite new to this time, the principles of flexible expression of A. Duncan were a sensation in Europe. With the help of simple natural movements of ancient dance, elements of free plasticity, elementary types of walking and running, she tried to reveal the image and theme of the music she danced to. ${ }^{16}$ A. Duncan influenced the formation of the rhythmic-plastic direction, which later formed the modern rhythmic gymnastics and rhythmic gymnastics for women.

15 Sosina V. Yu. (2019) Khoreohrafiia v sporti [Choreography in sports]. Kyiv: Olimpiyska Literatura.

${ }^{16}$ Sosina V. Yu. (2019) Khoreohrafiia v sporti [Choreography in sports]. Kyiv: Olimpiyska Literatura. 


\section{Ways of Technical and Aesthetic Sports and Choreography Mutual Enrichment in the Aspect of Their Further Development}

The path of integration of the choreography art and different sports, search for common features, mutual understanding, mutual enrichment was long and contradictory. For more than half a century, representatives of the "pure style" have fought for the separation of art from sport, and sport from art. However, the analysis of development trends of each of them shows that in the modern world this integration, interpenetration and synthesis will continue, contributing to the emergence of new areas of art and new sports ${ }^{17}$.

As it was already noted, the problem of sports and art integration is not new, but it has become especially important today. Scientists-theorists were able to find much in common together with a significant difference between them, which forces to decide on the possibility of integration, synthesis, the interpenetration of these elements of culture for their further development and mutual enrichment (V.I. Samusenkova, 1996; V.I. Stoliarov, 1998; A. Krolica, 2006).

Among the many attempts to integrate sports and art, an important one is occupied by those aimed at levelling the differences between them on the basis of the aesthetic and spiritual potential of sports ${ }^{18}$.

Among the most unexplored aspects of this problem, the authors single out the actual pedagogical, emphasizing that active classes in art disciplines (including choreography) or sports lead to a gap between spiritual and physical development, and fascination with art, contributing to the spiritual development of the individual, can cause deterioration of his health, while active sports - to the impoverishment of the spiritual world of $\operatorname{man}^{19}$.

The twenty-first century was a period of the rapid development of sports and physical culture, new species appeared, the affinity of which with the art of dance is no longer in doubt. Thanks to the use of musical orchestral

17 Sosina V. Yu. (2018) Shliakhy intehratsii khoreohrafichnoho mystetstva ta tekhniko-estetychnykh vydiv sportu [Shlyakhi of integration of choreographic art and technical-aesthetic types of sports]. Dance Studies, vol. 1, pp. 81-90.

${ }^{18}$ Kudashov V., Kudashova L. (2010) Rol' esteticheskikh vidov sporta pri sozdanii khudozhestvennogo obraza $\mathrm{v}$ sportivno-khudozhestvennykh predstavleniyakh [The role of aesthetic sports in creating an artistic image in sports and artistic performances]. Proceeding of the The international scientific conference dedicated to the $75^{\text {th }}$ anniversary of rhythmic gymnastics (Russia, St. Petersburg, November 6, 2009), St. Petersburg: National State University of Physical Culture, Sports and Health named after P.F. Lesgaft, pp. 19-27.

19 Samusenkova V. (1995) Integratsiya sporta s iskusstvom kak sotsial'nopedagogicheskaya problema [Integration of sport with art as a social and pedagogical problem] (PhD Thesis), Moscow: Russian State Academy of Physical Culture. 
accompaniment, as well as dance movements, new possibilities of the plasticity of the human body, open up.

Thus, arose new sports that belong to the group of technical and aesthetic, and in which it is the aesthetic orientation has a pronounced character. Each of them complements, modernizes, improves the other. For example, through the synthesis of two cultures, such new sports or physical culture and health activities as cheerleading, dance aerobics, sports rock ' $n$ ' roll, jazz-funk, pylon exercises, and others emerged.

Attempts by experts to combine completely "non-dance" sports with choreography have led to the emergence of freestyle (or figure skating); snowboarding (namely its "artistic" types); dances in the wind tunnel, where the result of the performances is a score given by the judges for performance skills, etc. It is in them that the phenomenon of integration of different types of choreography, acrobatics, sports and rhythmic gymnastics, swimming, skiing, etc. can be traced to the greatest extent. Performing such exercises in different environments (water, ice, snow, air space, special coating) increases the capabilities of athletes, promotes the emergence of new entertainment and complex elements and exercises. Recently, the world has learned about the emergence of artistic parachuting, which combines elements of gymnastics, acrobatics and choreography, which must show the athlete in the process of performing a long jump.

In addition, attempts at integration are associated with the search for areas of mutual enrichment of art and sport, which can occur, on the one hand, through the use of experience and means of plasticity arts (choreography) in technical and aesthetic sports, and on the other - the impact of sport on fashion, clothes, hairstyles, choreographic $\operatorname{art}^{20}$.

The constant complication of the performance technique, the growth of requirements for performances allows us to assume that people will soon work wonders of acrobatics and dance.

Thus, the analysis allows us to state that the integration of choreographic art and sports, associated with the manifestation of the culture of movement and artistry, can take place in two directions: further rapprochement and strengthening the relationship between them. The first direction involves further levelling the difference between these two elements of modern human

${ }^{20}$ Kudashov V., Kudashova L. (2010) Rol' esteticheskikh vidov sporta pri sozdanii khudozhestvennogo obraza v sportivno-khudozhestvennykh predstavleniyakh [The role of aesthetic sports in creating an artistic image in sports and artistic performances]. Proceeding of the The international scientific conference dedicated to the 75th anniversary of rhythmic gymnastics (Russia, St. Petersburg, November 6, 2009), St. Petersburg: National State University of Physical Culture, Sports and Health named after P.F. Lesgaft, pp. 19-27. 
culture on the basis of the achievements of each of them; the second is their possible unification into a single socio-pedagogical and cultural system.

\section{CONCLUSIONS}

Thus, we can identify the main factors that determine the possible ways of integration of sports and choreographic art, which are due to historical aspects of both human activities, aesthetic representation of the product of their activities, the importance of expressiveness, similar tools and methods of teaching and education. performance of movements, the presence of a prearranged program of actions (compositions), methods of musical accompaniment, requirements for morphological, functional and physical indicators, design of performances, costumes, etc.

Summarizing the above, we can say that sport and art are two elements of culture that are important for the realization of humanistic ideals and values, diverse and harmonious human development.

Despite some similar features, sports and art are fundamentally different from each other.

At present, the problem of integration, synthesis of sports and art is becoming increasingly important. The solution to this problem is possible because of the similarity of these two elements of culture, which are able to fruitfully influence and complement each other. There are two main and possible ways to integrate sport with art: the first - rapprochement, "smoothing" the differences between them on the basis of increasing the aesthetic and spiritual value of sport and the wider use of the competitive component in the field of art; the second is to strengthen the connection between sports and art, to unite them into a single socio-pedagogical and cultural system.

\section{SUMMARY}

Modern ballet is a complex synthesis of different directions and styles of choreography, circus art, acrobatics, supports and pyramids, elements of free plasticity art, exercises of artistic, aesthetic and gymnastics. Features of the use of choreography in technical and aesthetic sports show that choreographic training is an integral part of the training process, and it is based on classical exercise, which together with other means of choreography must meet the requirements of competition rules, trends and specifics of sports athletes in each sport. The integration of art and sports takes place in different parts of modern culture, but most of all this synthesis is noticeable in the choreographic art and technical and aesthetic sports, where it ultimately causes the most controversy. 


\section{REFERENCES}

1. Aleksanyan S., Koyumdzhyan E., Sharina O. (2016) Sredstva $i$ metody khoreografii $v$ tantseval'noy aerobike [Means and methods of choreography in dance aerobics]. Yekaterinburg: Ural University Publishing House. (in Russian)

2. Kudashov V., Kudashova L. (2010) Rol' esteticheskikh vidov sporta pri sozdanii khudozhestvennogo obraza $\mathrm{v}$ sportivno-khudozhestvennykh predstavleniyakh [The role of aesthetic sports in creating an artistic image in sports and artistic performances]. Proceeding of the The international scientific conference dedicated to the 75th anniversary of rhythmic gymnastics (Russia, St. Petersburg, November 6, 2009), St. Petersburg: National State University of Physical Culture, Sports and Health named after P.F. Lesgaft, pp. 19-27.

3. Panasenko Yu.V. (ed.) (2019) Tantseval'naya pedagogika budushchego: teoriya i praktika [Dance pedagogy of the future: theory and practice]. Materials of the International Scientific and Practical Conference of the Dancehelp company in conjunction with the Moscow State Budgetary Institution of Culture "CC" Inspiration" (Russia, Moscow, July 13, 2019). Moscow: ROSA. (in Russian)

4. Prokopovich L. V. (2018) Issledovanie artistizma i teatral'nosti v sporte kak v kul'turnoy praktike [Research of artistry and theatricality in sport as in cultural practice]. Molodyi vchenyi, no. 7 (2), pp. 350-353.

5. Radchenko S. I. (2020) Perspektivnye napravleniya sovershenstvovaniya metodiki prepodavaniya klassicheskogo tantsa $\mathrm{V}$ sisteme srednego professional'nogo khoreograficheskogo obrazovaniya [Prospective directions of improving the methods of teaching classical dance in the system of secondary professional choreographic education]. Pedagogika iskusstva [Pedagogy of Art] (electronic journal), no. 1, pp. 111-118. Retrieved from: http://www.art-education.ru/sites/default/files/ journal_pdf/radchenko_111-118.pdf (accessed 7 October 2020).

6. Samusenkova V. (1995) Integratsiya sporta s iskusstvom kak sotsial'no-pedagogicheskaya problema [Integration of sport with art as a social and pedagogical problem] ( $\mathrm{PhD}$ Thesis), Moscow: Russian State Academy of Physical Culture.

7. Sosina V. Yu. (2019) Khoreohrafiia $v$ sporti [Choreography in sports]. Kyiv: Olimpiyska Literatura. (in Ukrainian)

8. Sosina V. Yu. (2018) Shliakhy intehratsii khoreohrafichnoho mystetstva ta tekhniko-estetychnykh vydiv sportu [Shlyakhi of integration of choreographic art and technical-aesthetic types of sports]. Dance Studies, vol. 1, pp. 81-90. 
9. Stolyarov V. I. (1997) Sport i iskusstvo: skhodstvo, razlichie, puti integratsii [Sport and art: similarity, difference, ways of integration]. Sport, dukhovnye tsennosti, kul'tura [Sport, spiritual values, culture]. (Vol. 5). Moscow: Humanitarian Center "Spart" RGAFK, pp. 101-265.

10. Stolyarov V. I., Samusenkova V. I. (1996) Sovremennyy sport kak fenomen kul'tury $i$ puti ego integratsii $s$ iskusstvom (teoriya, metodologicheskie podkhody, programmy) [Modern sport as a cultural phenomenon and ways of its integration with art (theory, methodological approaches, programs)]. Sport i iskusstvo: al'ternativa - edinstvo - sintez? [Sport and art: alternative - unity - synthesis?] (Vol. 3.). Moscow: Humanitarian Center "Spart” RGAFK, pp. 49-178.

\section{Information about the author: Sosina Valentyna orcid.org/0000-0003-4866-532X $\mathrm{PhD}$ in Pedagogy} Lviv State University of Physical Culture named after Ivan Boberskyi 11, Kostiushko str., Lviv, 79007, Ukraine 